\title{
POLITICAL COMMITMENT OF LEADERS, CHANGE READINESS AND AFFECTIVE COMMITMENT FOR IMPLEMENTATION OF BSC REFORM IN ETHIOPIA
}

\author{
Challa Amdissa Jiru \\ Addis Ababa University, Ethiopia, Email: challaamdissa9@gmail.com
}

\begin{abstract}
Leader's political commitment has important role in the BSC reform process from introduction of BSC through the implementation and evaluation of its outcomes. However, no adequate study has been conducted on the relationship between political commitment and the implementation of reform programs in Ethiopia. This study examines the relationships between leader's political commitment, employee's change readiness and their commitment for implementation of BSC programs; based on primary data collected from 191 employees working in 15 different organizations of the Federal and regional governments of Ethiopia by using survey method. It was found that leaders in the public sector have some political commitment to implement BSC reform; but its adequacy is doubtful particularly in resources allocation for implementation of reforms. Correlation analysis shows all the three dimensions of political commitment have positive linear relations with change readiness. It also shows while budgetary commitment and institutional commitment have positive associations with employee commitment for implementing reform, expressed commitment has no linear relationship with employee commitment for implementation of BSC reform. Moreover, commitment for reform implementation has stronger correlation with change readiness of employees than political commitment of their leaders. Hence we concluded that the relation between political commitment and reform implementation is mediated by change readiness.
\end{abstract}

\section{INTRODUCTION}

Public service reforms, with their foundations in the New Public Management (NPM) movements, basically attempt to introduce in the public sector, the notion of efficiency using the private sector management model. Public service reforms are driven by the contemporary thoughts that require business approach in the delivery of services in government. In response to the growing demands of citizens, 
Prestige International Journal of Management \& IT-Sanchayan, Vol. 8 (2), 2019, pp. 15-36, ISSN : 2277-1689 (Print), 2278 - 8441 (Online)

business management techniques such as Business Process Reengineering (BPR) and Balanced Scorecard (BSC) are being adopted with a view to improve the responsiveness of governments to public concerns, improving the quality of public goods and services, increasing the efficiency of service delivery and promoting accountability and ethical values (Ayee, 2001).

With emergence of NPM movements, public organizations have been required to operate in increasingly market type of services which have led to increasing pressure to adopt results-oriented reforms. Since the 1990s, the most widely implemented of such reforms is result oriented performance management (Yang \& Sanjay K. Pandey, 2008). As part of the reform initiatives, performance management in general and result oriented performance management has attracted the attention of most governments in developing countries. As Berry (2007) strongly argues, result oriented management increases political and administrative accountability by making it easier for managers to match targets with corporate objectives. The introduction and effective implementation of BSC, enhance accountability for performance and transparency in service provision (Berry, 2007; Voet, Kuipers, \& Grueneveld, 2015; Niven, 2002; Hoque, 2013).

In result oriented management system, performance results are clearly communicated to stakeholders and are used for the purpose of policy making, management, and evaluation. Broadly defined, managing for results relates to management techniques such as strategic planning, performance measurement, customer service, quality improvement, management-by-objective (MBO) and benchmarking (Yang \& Sanjay K. Pandey, 2008). Result oriented performance management system is a practical and rational management philosophy in which managers are forced to develop specific individual and group goals, develop appropriate action plans, organize the resources properly and establish needed control standards (Neiger, 2009; Niven, 2002). BSC as the most commonly used approach to strategic performance management is a strategic planning and management tool which aligns business activities to the vision and strategy of the organization, improves internal and external communications, and uses for monitoring organization performance against strategic goals (Niven, 2002; Kureshi, 2014). Both result oriented performance management and balanced scorecard have a clear strategic orientation, which makes imperative the availability of political commitment.

The availability of strong demand for reform in the performance management system is not a sufficient condition for the successful implementation of the initiatives. As different scholars example (Hoque, 2013; Berry, 2007; Biden, Mziu, \& M.\& Suhaimi, 2014; Ronchetti, 2006) rightly argued, several factors directly or indirectly affect the success of result oriented performance management in general and balanced scorecard in particular. More importantly, as BSC, beyond simple performance management, focuses on strategic approach to managing 
Political Commitment of Leaders, Change Readiness and Affective Commitment For Implementation of Bsc Reform in Ethiopia

organizations (Rosen \& L. and Lydia, 2012), the role of leadership is magnificent from the introduction of the system all through the implementation and evaluation of the reform outcome.

In the bid to introduce BSC approach to performance management in the public sector, (Niven, 2002) argues that, organizations are strongly required to assess and determine the availability of initiatives for change. This implies that right from the beginning, leader's political commitment, among other factors, plays a key role for the success or failure of BSC systems. It is natural for public employees to assume that leaders support can bring in financial, human, and technological resources for implementation of the reform program.

Study conducted in Ministry of Culture and Tourism of Federal Democratic Republic of Ethiopia (FDRE) shows the failure of strategic performance management system was attributed to lack of leadership competence and commitment. In that organization only $5 \%$ of the employees understood the strategy and only $25 \%$ of the leaders had the commitment to link performances to corporate strategies (MoCT, 2011). This study implies that in a situation where $95 \%$ of the employees were unable to understand and internalize corporate strategies, the problem can be attributed to the lack of competence and/or political commitment of the leaders and lack of change readiness among employees of the organizations. Similarly, it can be argued that in an organization where $75 \%$ of the leaders lack commitment to align the efforts to corporate goals and create the big picture, strategic performance management initiatives will most likely fail.

Despite the fact that the role of political commitment for implementation of public program, studies on the role of political commitment in the implementation of reform programs in the Ethiopian public sector are scanty. Few studies conducted in the Ethiopian reform initiatives mainly focus on other factors than leadership political commitment. Nebiyou (2010) found out that the implementation of civil service reform in Ethiopia was challenged by lack of managerial skills. However, his study did not specifically address the issues of leaders' political commitment as well as its role in the implementation of BSC in public organizations. Similarly, a study by Solomon(2013), deals with general issues, lessons and future directions of civil service reform in Ethiopia with very limited emphasis on the role of political commitment.

Moreover, Solomon's study assesses civil service reforms as the whole and does not specifically investigate the implementation of BSC in Ethiopian public organizations. Yosef (2011) studied civil service reform in Adama City and made a conclusion that capacity building training, incentives, coordination and communication and changing the attitudes of leaders are essential in the implementation of reform programs. However, the study has a limited scope as it 
Prestige International Journal of Management \& IT-Sanchayan, Vol. 8 (2), 2019, pp. 15-36, ISSN : 2277-1689 (Print), 2278 - 8441 (Online)

was conducted in a specific regional town and it did not also specifically focus on the role of political commitment and change readiness.

Many others studies e.g. (Tadesse, 2013; Getachew, 2007; Ayee, 2001); have investigated factors of public sector's reform programs, however, none of these studies have explicitly investigated the relation of leaders' political commitment with change readiness and implementation of BSC reform programs. Moreover, no study hasspecifically addressed the issues of BSC implementation in relation to leaders' political commitment in the public sector in Ethiopia.

In response to this research gap, this study tried to assess how leaders' political commitment contributes to the employee's change readiness and commitment for the implementation of BSC in public sector organizations in Ethiopia. This study attempted to provide answer to the research question; how does political commitment affect the affective commitment of employees for implementation of BSC reform in the Ethiopian public sector organizations?

The study has the following specific objectives.

I. To explore the level of political commitment in the implementation of BSC in the public sector in Ethiopia

ii. To analyze the association between political commitment of the leader with employees' change readiness in the public sector in Ethiopia

iii. To analyze the association between political commitment of the leader with employees' commitment to BSC implementation in the public sector in Ethiopia

iv. To assess the relationship between employee's change readiness and their commitment to BSC implementation in the public sector in Ethiopia

In the last three decades, different reforms have been introduced in Ethiopia to achieve the country's social economic and political goals. Adoption of BSC as the planning and management tool is one of such reforms introduced to the government organizations in Ethiopia with aim to improve efficiency and effectiveness of public service delivery. From those many reform agendas being introduced by government of Ethiopia, this study was delimited to the factors that influence the commitment of employees for implementation of BSC. Similarly, from the many factors that may determine the commitment for BSC implementation, only the role of leader's political commitment and employee readiness for change were considered.

The significance of this research can be seen from different angles. In the first place, the result of this research may help government organizations to re-consider the importance of political commitment of leaders for the successful implementation of the reforms. In addition, the study will also show direction for other researchers who want to further their study on related areas. 
Political Commitment of Leaders, Change Readiness and Affective Commitment For Implementation of Bsc Reform in Ethiopia

\section{THEORETICAL FRAMEWORK OF POLITICAL COMMITMENT, CHANGE READINESS AND PERSONAL COMMITMENT FOR BSC IMPLEMENTATION}

\section{Basic Concept of Leader's Political Commitment}

Though, government reform has attracted the interest of scholars and practitioners (Armenakis \& Bedeian, 1999; Pettigrew, Woodman, \& Cameron, 2001; Burnes, 2004; Whitely \& Whitely, 2007), many of organizational reform efforts are unsuccessful (Kotter, 1995; Judge \& Douglas, 2009) due to numerous factors that might have different degrees of influence in different contexts, e.g. different countries. Among these factors, leaders' political commitment is perceived to be paramount important (Sinnappan Santhidran, 2013). If a program is not accepted and backed by the politicians and the top management, its implementation process may actually never take place. Political commitment should be seen as a driving force that stimulates the management cycle www.localmanagement.eu. According to (Willy, 1995), It is common to hear that reform being adopted was failed on implementation because of lack of commitment from organizational leaders.

Heaver and Israel (1986) pointed out that regardless of importance of leader's political commitment for program implementation, the concept lacks precise definition. Willy (1995) describes 'commitment' as a classic 'black box', a cloudy concept habitually invoked in reform(Willy, 1995). Political commitment is driven by a critical scrutiny of the exercise of power, and either the endorsement or the rejection of the reasons and structures that shape the institutional rules on the basis of which that power is exercised and reproduced(YPI, 2016).

More recently, Ashley (2014) explains political commitment along three dimensions: expressed commitment, institutional commitment and budgetary commitment. According to this model, expressed commitment is verbal declarations of support for an issue by high-level, influential political leaders. The institutional commitment is associated with specific policies and organizational infrastructure in support of a given program, while the budgetary commitment refers to allocations of the necessary resources for implementation of the adopted reform, in a relative to a particular benchmark. This conceptualization of political commitment is adopted is adopted in this paper and, the three dimensions of political commitment are further explained in the subsequent sections.

\section{Expressed Commitment}

Expressed commitment is a commitment shown by statements made by leaders. Measurement on this dimension usually entails counting the frequency of positive statements made by leaders on different media. Although verbal declaration of the 
Prestige International Journal of Management \& IT-Sanchayan, Vol. 8 (2), 2019, pp. 15-36, ISSN : 2277-1689 (Print), $2278-8441$ (Online)

supports to a program is a useful indicator of commitment, it suffers from several limitations. With this regard, the true intentions of government, as verbally declared may not in congruent with its capability to carry out program.

Levy (1993) uses adoption as a proxy for intention, which is different from implementation. Reforms being adopted may not be implemented, because public pronouncements are not sufficient for getting reforms implemented, sometimes, pronouncements are not necessary as a number of reforms have been implemented even though they were never adopted.

Public pronouncements however, confer ownership of the program. If capability is limited and opposition is relatively strong, governments may not wish to declare their intent. But they may be committed without explicit declaration of reform program (Morrissey, 1995). Thus, public declaration of intent is a sign of some commitment, but its absence does not imply nonexistence of commitment. For this reasons, expressed commitment is the weakest indicator of political commitment.

\section{Institutional Commitment}

Political commitment is also expressed by a critical step in setting up the basic "institutions" or bureaucratic infrastructure needed to implement the reform. Pelletier et al (2011) described institutional commitment as the action required to translate intentions into tangible outputs like: introducing national policy or setting strategic plan. Fox (2011) distinguishes between expressed commitment and institutional commitment as the first is rhetoric in nature and the later is demonstrated with adoption of laws and policies supportive of the reform implementation.

Compared to expressed commitment, an institutional commitment is advanced level of political commitment, because by building up institutions such as policies and procedures that are hard to undo once established, institutional commitment goes far beyond mere expression of what are desired (Ashley, Allison, Radhika, \& J. G and Till, 2011). This level of political commitment therefore constitutes an additional component of political commitment.

Although institutional commitment is better than expressed commitment as indicator of leaders' political commitment, resource limitations may constrain the implementation of reform programs in the public sector. However, implementation of reform is a function of leaders' practical action such as formulation of policies and strategies, promulgation of laws, development of action plan, issuance of directives and other action of leaders that provide guidance to employees who implement the reform program. 
Political Commitment of Leaders, Change Readiness and Affective Commitment For Implementation of Bsc Reform in Ethiopia

\section{Budgetary Commitment}

Expressed commitment and institutional commitment alone may not be sufficient to provide a complete picture of government commitment, unless public pronouncements and enactment of policies are accompanied by adequate allocation of resources that are necessary for effective implementation of reform program. Budgetary commitment signalled not only as a promise about the future, but also the matching up of words with action. In other words, expressed commitment is measures what government said and budgetary commitment measures what it ultimately did. Similarly, according to (Ashley, Yarlini, Cheng, \& and Michael, 2014), budgetary commitment allows for an evaluation of whether commitment lives up to verbal rhetoric and concrete commitments. Expenditure actually dispersed rather than pledged provides a more concrete measure of commitment,(Ashley, Allison, Radhika, \& J. G and Till, 2011).

Moreover, according to Lieberman(2009), commitment in term of relative resource allocations, is more objective measure of commitment than commitment in terms of promise. Because resource allocation can be tracked over time and compared across different organizational leaders. A better indicator of leader's political commitment for reform implementation is funding for reform programs. High levels of national funding can result only when the political commitments exist to make reforms a priority program for scarce national resources.

One of the weaknesses of budgetary commitment as a measure of political commitment is difficulty of finding information about the resources being consumed. Furthermore, on the account of inefficiency in resource use, the amounts of resources expend may not be in parallel with outputs and outcomes. Some studies rely on service delivery or customer satisfaction as measure of commitment, instead of relying on commitment in terms of resource allocations. But, this approach is problematic; since service delivery or customer satisfaction are outputs of political commitment, not measures of commitment themselves (Ashley, Allison, Radhika, \& J. G and Till, 2011).

\section{Change Readiness}

On the basis of evidences from Estonia, Ruth (2004) points out that the failure in reform implementation is associated with readiness to change among employees. Readiness for change refers to having the right mindset for change. Implementation of reform depends on the employees' understanding and their beliefs on the importance of proposed change. According to Armenakis, Harris, \& Mossholder,(1993) leadership may influence both commitment to change and the employees readiness for change. From these arguments, we can infer that change readiness can be facilitated by leadership political commitment, and in turn, change readiness influences commitment to implement change. 
Prestige International Journal of Management \& IT-Sanchayan, Vol. 8 (2), 2019, pp. 15-36, ISSN : 2277-1689 (Print), $2278-8441$ (Online)

\section{Affective Commitment}

Employee commitment is a multidimensional construct (Jackson, Meyer, \& XiaoHua (Frank) Wang, 2013), but accompanied by well-established measures (Allen \& Meyer, 1990; Meyer, Allen, \& Smith, 1993), and has received considerable empirical support (Allen \& Meyer, 1990; Meyer, Stanley, Herscovitch, \& Topolnytsky, 2002). The three dimensions of employee commitment are affective commitment, continuance commitment and normative commitment. Affective commitment reflects an emotional attachment to, identification with, and involvement in organization, while continuance commitment reflects attachment with organization due to perceived costs associated with discontinuing employment relationship. Normative commitment reflects a sense of obligation on the part of the employee to maintain membership in the organization.

The three types of commitment can be distinguished on the basis of psychological state, or mindset, presumed to characterize the commitment. Affective commitment is supposed to have the strongest positive correlations with implementation of reform(John \& P. Meyer and Catherine, 2000).

John \& P. Meyer and Catherine (2000) argue that employees' commitment to the organization can take various forms, and the same is true in case of commitment for implementation of programs. The focus of this research is employee commitment to implement BSC reform and was measured using six survey items. As commitment binds an individual to an organization's program goals, committed employees put necessary effort for implementation of reform initiatives (Strauss, Griffin, \& Rafferty, 2009).

\section{RESEARCH DESIGN}

Cross-sectional data were collected through the use of questionnaire method. Survey was chosen in order to make generalization about association among different dimensions of leaders' political commitment, change readiness and employees' commitment for implementation of BSC in the public sector in Ethiopia.

This empirical research investigated the association between political commitment of leaders and employee's readiness for change and commitment for BSC implementation, which is key to determine success or failure of organizational reforms. Towards this end, political commitment of leaders in the selected organizations in the public sector in Ethiopia was measured by using the political commitment model as designed by (Ashley, Allison, Radhika, \& J. G and Till, 2011) and (Ashley, Yarlini, Cheng, \& and Michael, 2014).Similarly Employee change readiness and employee commitment for BSC implementation were measured by using a model developed by (Sinnappan Santhidran, 2013).Ashley (2014) describes 
Political Commitment of Leaders, Change Readiness and Affective Commitment For Implementation of Bsc Reform in Ethiopia

the concept of political commitment along three variables as follows:

- Expressed commitment (EC) public declarations in support for implementation of BSC by organizational leaders;

- Institutional commitment (IC) enactments of specific laws and policies in support of BSC implementation; and

- Budgetary commitment (BC) earmarked allocations of resources for implementation of BSC.

- Two variables: change readiness and commitment for BSC implementation were supposed to have correlation with political commitment. They are defined by (Sinnappan Santhidran, 2013)as follows.

- Change Readiness (CR) refers to openness to change which includes the support for change and positive effects of potential consequences of change.

- Commitment for BSC Implementation (CBI) was being assessed by affective responses to change efforts.

A Likert's five-point scale form of questionnaire was developed to measure the research variables. Several items were used to measure each of these independent and dependent variables with five-point scale measurement from strongly disagree to strongly agree (see the survey item in appendix I). Reliability of the survey instruments was tested with Cronbach's Alpha by conducting pilot survey before using the questionnaires.

Because of the nature of the study, the research employed quantitative methods of analysis was used to organize and interpret the data. The variables were measured and comparisons were made by using descriptive statistics like frequencies, relative frequencies, mean and standard deviations. Finally, the associations between dimensions of political commitment, readiness for change and employee's commitment for implementation of BSC were measured using correlation coefficient to draw conclusion on the antecedents of BSC implementation in the public sector in Ethiopia. To support the presentation, and analysis of quantitative data, Statistical Packages for Social Sciences (SPSS) Version 20 was used. This version is chosen due to the fact that it is a comprehensive on having multiple advanced features.

The study targets on diverse group of employees of selected public organizations working in organizations of federal government of Ethiopia and bureaus of regional states' governments. Samples were taken from employees of fifteen organizations, where BSC reforms have been implemented. The fifteen organizations were selected based on multi-stage random sampling method. The Federal Democratic Republic of Ethiopia has nine regional states and two autonomous city administrations with somehow below regional status in terms of political powers. Ministries of the federal government, three of the nine regional states, and one of the two city administrations were included in the research. 
Prestige International Journal of Management \& IT-Sanchayan, Vol. 8 (2), 2019, pp. 15-36, ISSN : 2277-1689 (Print), 2278 - 8441 (Online)

Oromia, which is the largest region (both in terms of population and area coverage) and SNNP region, which is known by having the most diverse population were included in the study by representing the principal regions. Similarly, Somali region, which is biggest among the peripheral regions, was included in the study. Based on the same criterion, a primate city of Addis Ababa was chosen from the two city administrations.

A next stage of sampling is selection of organizations from Federal government and from the regions included in the study. With this regard, at average, three organizations were selected from each of the regions and from the federal government organizations to constitute fifteen organizations. Following selection of the organizations, the next step was selection of people who represent each organization. Samples were taken from each organization independently by using payrolls as sample frame. By using simple random sampling method, we planned to take 25 samples from payroll lists of each organization to make a total sample size $375(25 * 15)$.

However as a result of non-responses, the actual participants of the research were191, which denote the response rate was about 51 percent. Response rate was found to be low regardless of many efforts being taken to encourage participation. To reduce the impact of none responses on sample size respondents who did not cooperate with data collectors or not accessible due to absence and other reasons were replaced by another randomly selected person. Furthermore, to confirm with the ethical procedures, the purpose of the research was communicated to the survey respondents and their consents were acquired, before their participation. However, the response rate was still low due to our preference to random sampling technique.

\section{DATA PRESENTATION AND ANALYSIS}

\section{Respondents}

191 employees from 15 different organizations of Federal government and regional governments responded to questionnaire survey (See list of participating organizations in appendix 3). These respondents were employees of all age group. While half of respondents reported that they were in the age group of 31-43, respondents in age group of 44-56 and 18-30 accounts for 27 percent and 20 percent respectively. About 3 percent of respondents reported that they were above the age of 57 years. In terms of sex distribution of participants, male respondents outnumbered female respondents with the former 74 percent and the later 26 percent. The other variable being used to identify respondents was level of education. With this regard, other than 4 percent of respondents with education level of diploma or below, the rest were first degree holders and second degree holders and they account for about 73 percent and 23 percent of respondents 
Political Commitment of Leaders, Change Readiness and Affective Commitment For Implementation of Bsc Reform in Ethiopia

respectively. In terms of experience, about 35 percent of respondents were found to be employees with less than 5 years of service, while the next largest group (27 percent) were those who have 6-10 years of services. Respondents with 11-15 years, 16-20 years and above 20 years of experience constitute 12, 13 and 13 percent respectively (See frequency table in appendix 2 ).

Political commitment, Change readiness and Affective Commitment for BSC Implementation

\begin{tabular}{|l|r|r|r|}
\hline \multicolumn{1}{|l|}{ Descriptive Statistics } & \multicolumn{1}{|c|}{$\mathrm{N}$} & \multicolumn{1}{c|}{ Mean } & Std. Deviation \\
\hline & 191 & 3.4398 & .74967 \\
\hline Expressed Commitment & 191 & 3.6395 & .72722 \\
\hline Institutional Commitment & 191 & 3.1749 & .85069 \\
\hline Budgetary Commitment & 191 & 3.6230 & .97625 \\
\hline Readiness of Employees for Change & 191 & 3.7801 & .71961 \\
\hline $\begin{array}{l}\text { Commitment to Reform by } \\
\text { Employee }\end{array}$ & 191 & & \\
\hline Valid N (listwise) & & & \\
\hline
\end{tabular}

In views of the respondents, there was modest political commitment to implement BSC reform in different government offices. From the three aspects of political commitment; the mean value of budgetary commitment was found to be lowest while the mean value of institutional commitment was the highest. Employees rated their own readiness for change and their own commitment for implementing BSC program in their respective organizations, which were perceived to be higher than the political commitment of leaders in their respective organizations.

The measure of correlations between each of the three dimensions of political commitment with change readiness and with commitment to reform by employees show that budgetary commitment is better in explaining change readiness and employee commitment for BSC implementation than expressed commitment and institutional commitment.

This fact indicates that the improvement of resource supply in office is more effective than improvement of communication and introduction of new policies or laws in order to enhance change readiness and commitment of employees for implementation of BSC programs in the public sector in Ethiopia. 
Prestige International Journal of Management \& IT-Sanchayan, Vol. 8 (2), 2019, pp. 15-36, ISSN : 2277-1689 (Print), 2278 - 8441 (Online)

\begin{tabular}{|c|c|c|c|}
\hline \multicolumn{4}{|c|}{ Correlations } \\
\hline & & Change Readiness & $\begin{array}{c}\text { Commitment to } \\
\text { Reform by Employees }\end{array}$ \\
\hline \multirow{3}{*}{$\begin{array}{l}\text { Expressed } \\
\text { Commitment }\end{array}$} & Pearson Correlation & .218 & $.088^{* *}$ \\
\hline & Sig. (2-tailed) & .003 & .224 \\
\hline & $\mathrm{N}$ & 191 & 191 \\
\hline \multirow{3}{*}{$\begin{array}{l}\text { Institutional } \\
\text { Commitment }\end{array}$} & Pearson Correlation & $.258^{* *}$ & .149 \\
\hline & Sig. (2-tailed) & .000 & .039 \\
\hline & $\mathrm{N}$ & 191 & 191 \\
\hline \multirow{3}{*}{$\begin{array}{l}\text { Budgetary } \\
\text { Commitment }\end{array}$} & Pearson Correlation & $.410^{* *}$ & $.361^{* *}$ \\
\hline & Sig. (2-tailed) & .000 & .000 \\
\hline & $\mathrm{N}$ & 191 & 191 \\
\hline \multirow{3}{*}{ Change Readiness } & Pearson Correlation & $1^{* *}$ & $.588^{* *}$ \\
\hline & Sig. (2-tailed) & & .000 \\
\hline & $\mathrm{N}$ & 191 & 191 \\
\hline
\end{tabular}

**. Correlation is significant at the 0.01 level (2-tailed).

*. Correlation is significant at the 0.05 level (2-tailed).

Correlation coefficient was used to see the type of linear relationships between each dimension of political commitment of leaders, change readiness of employees and commitment of employees for BSC implementation in the public sector in Ethiopia. The correlation coefficient shows the evidence for existence of linear relationships between some dimensions of political commitment and employee change readiness and commitment for BSC implementation as described below.

To begin with the analysis of the relationship between expressed commitment and readiness for change, the correlation coefficient was found to be 0.218 , at sig 0.0032 tailed. The result shows existence of positive linear relationship between expressed commitment of leaders and change readiness of employees. The correlation between expressed commitment of leader and employee commitment for BSC implementation was ( $r=0.088$ at sig 0.224 2-tailed), which is not statistically significant at a level of 0.05 .The result does not support the positive association between expressed commitment of leader and employee commitment for BSC implementation.

Contrary to expressed commitment of leaders, the level of institutional commitment explains both change readiness of employees and employee commitment for BSC implementation in the public sector in Ethiopia. The result of correlation of institutional commitment with change readiness and correlation of Institutional commitment with commitment of employee for implementation of BSC were both statistically significant at $(\mathrm{p}=0.000$ 2-tailed) and at $(\mathrm{p}=0.039$ 2-tailed) respectively. These results show that evidences exist to support the positive relationship of institutional commitment with both employee readiness for change and employee commitment for BSC implementation in the public sector in Ethiopia. 
Political Commitment of Leaders, Change Readiness and Affective Commitment For Implementation of Bsc Reform in Ethiopia

The relation of budgetary commitment with both change readiness and commitment for BSC implementation were statically significant with $p=0.000$ and $p=0.000$. These results of statistical test support the existence of evidences for positive association between budgetary commitment and change readiness as well as the existence of evidences for positive association between budgetary commitment and employee commitment for change.

To summarize the above presentation, based on analysis of the existence of linear relationship among the variables, the statistical results show evidence for existence of positive relation between expressed commitment and change readiness, but the test result does not show existence of any evidence for positive linear relationship between expressed commitment of leaders and employees' commitment for BSC implementation. On the other hand, the statistical test result shows the existence of evidence for positive linear relationship of institutional commitment and budgetary commitment with both change readiness and employee commitment for change.

Apart from test of linear relationships that show the direction of relationships between variables, it is also important from practical point of view to present the strength/weakness of the correlation among variables. Correlation coefficient was used to measure the associations among the variables; because it is an excellent measure of effect size for the association between two continuous variables (Dewberry, 2004). The correlation coefficient may range between 0 if there is no association between two variables, to 1 if there is a perfect positive relation between them, and -1 if there is a perfect negative relation between them(Dewberry, 2004). As cited in (Dewberry, 2004), Cohen and Cohen establishes the convention that in organizational research, and social science research generally, a small effect is viewed as a correlation of about 0.1 (or -0.1 for a negative correlation), a medium effect is a correlation of about $0.3(-0.3)$, and a large effect would be a correlation of $0.5(-0.5)$ or more(Dewberry, 2004).

Because the correlation coefficient is a direct measure of effect size, it is always a good idea to consider how large it is and, perhaps, to compare it to the convention for the effect sizes of small correlations (around 0.1), medium-sized ones (around 0.3 ) and large ones (0.5 and over) (Dewberry, 2004).Accordingly, the directions of an association between all variables were found positive but the strengths of the associations vary.

The correlation between expressed commitment and change readiness was 0.218 , which is the lowest among the associations between all dimensions of political commitment and change readiness. The association between budgetary commitment and change readiness is stronger with $r=0.41$ than the association between institutional commitment and change readiness with $r=0.258$. We can conclude based on this result, that change readiness is associated more with 
Prestige International Journal of Management \& IT-Sanchayan, Vol. 8 (2), 2019, pp. 15-36, ISSN : 2277-1689 (Print), 2278 - 8441 (Online)

practical action of leaders such as setting necessary policy environment and allocating necessary resources than verbal expression of leaders.

Similar result was found regarding associations between dimensions of political commitment of leaders as perceived by employees and affective commitment of employee for BSC implementation. No evidence was found to support the linear relationship between expressed commitment of leaders and employee commitment for BSC implementation in the public sector in Ethiopia, as $r$ is close to 0 . While the association between institutional commitment and employee commitment for BSC implementation was weak $(r=0.149)$, the association between budgetary commitment and employee commitment for BSC implementation was found medium $(r=0.361)$. On the other hand, stronger association was found $(r=$ 0.588 ) between employee change readiness and employee commitment for BSC implementation in the public sector in Ethiopia.

Correlation coefficient can be expressed through percentage of variance in one variable accounted for by another variable (or vice versa) can be worked out simply by squaring the correlation coefficient between them and multiplying by 100(Dewberry, 2004). Expressed in this way, the variance in employee commitment for implementation of BSC can be accounted by 2 percent for institutional commitment, by 13 percent for budgetary commitment and by 35 percent for employee change readiness. In the same manner, the variance in employee change readiness is attributed by 4.75 percent for expressed commitment, by 6.65 percent for institutional commitment, and about by 17 percent for budgetary commitment. The result of correlation shows that the effect size between change readiness and each of the political commitment dimensions is larger than the effect size between affective commitment and each of the dimensions of political commitment.

\section{FINDINGS AND DISCUSSIONS}

As indicated in the theoretical part of this paper, expressed commitment, institutional commitment and budgetary commitment are indicators of leader's political commitment for reform implementation. Though political commitments of leaders in the public sector in Ethiopia were not high, the statistical result supports the perspective of those who argue that all forms of leaders' political commitments have positive relations with change readiness. Except the expressed commitment, the remaining dimensions of political commitment have also positive relations with employee commitment for implementation of BSC. This finding has two implications. From theoretical perspective, it substantiates the line of existing arguments with evidence supporting the existence of relationships between political commitment and change readiness as well as the relationship between political commitment and affective commitment for BSC implementation; except in case of between expressed commitment and affective commitment for implementation of BSC. From practical point of view, its message is that 
Political Commitment of Leaders, Change Readiness and Affective Commitment For Implementation of Bsc Reform in Ethiopia

organizations should give emphasis to political commitment in order to enhance the proper implementation of their reform program, because increased political commitment will be accompanied by increased affective commitment for reform implementation. The details of discussions on the relationships between the variables are presented in the following paragraphs.

The public speech about the urgent need for reform by leaders, campaigns for raising awareness about importance of reform, and attention given to reform by higher officials in their official speeches are among indicators of expressed commitment. The encouraging speech of high-ranking government officials and team leaders about reform indicate government's desire for taking ownership of reform, government's transparency and its enthusiasm to explicitly take responsibility for results of its research programs. In this aspect, there is no doubt on the importance of expressed commitment for implementation of BSC or any other reform. However, what the data show is that employees in regional governments and federal government of Ethiopia were little influenced by speeches of their leaders. Therefore, there is a need for further research on the factors for effectiveness of communication by political and organizational leaders in influencing attitude and behaviour of employees. Political leaders should build trust so that they will be heard by their employees and in turn their communications will influence readiness for change and personal commitment of employees for successful implementation of BSC programs.

Promulgation of laws to facilitate the change process, adoption of reform policy, inclusion of reform implementation strategy in national development plan, establishment of organizational setting for inter sectoral coordination of reform, and formulation of organizational level action plan for implementation of reform are used as indicators of Institutional commitment. In Ethiopia, to some degree government put in place such conditions for facilitating implementation of reforms in general and BSC in particular. These conditions include promulgation of laws, adoption of policies and strategies, development of action plan, issuance of directives to facilitate the implementation of BSC programs in different government bureaus. Such actions were considered by employees as practical demonstration of government's political commitment for implementation of BSC tools; as a result the institutional commitment was the highest rated from the three dimensions of political commitment by view of employees. Institutional commitment has positive association with both change readiness and with employee commitment for implementation of BSC, though these associations were found weak.

As indicated in data analysis part, budgetary commitment is better indicator of leader's political commitment for reform implementation than both expressed and institutional commitments. Our data support this perspective in that budgetary commitment has stronger correlation with change readiness and employee 
Prestige International Journal of Management \& IT-Sanchayan, Vol. 8 (2), 2019, pp. 15-36, ISSN : 2277-1689 (Print), 2278 - 8441 (Online)

commitment for implementation of BSC than institutional commitment and expressed commitment. Among resources that may be required for implementation of reform program may include: manpower, financial resources, information, office facilities, and information and communication technologies. While availability of these resources was poorly rated, it has however the strongest association with change readiness and affective commitment for implementation of BSC.

It is to be noted that we did not get the data that show the exact amount of resources being consumed for implementations of BSC programs; instead we measured the adequacy of resources allocated for implementation of BSC using personal opinion of employees. Similarly, the result has to be used with caution regarding the scope of the study. This study has not gone beyond assessment of commitment for reform; hence service delivery or customer satisfaction was not studied.

Another finding important to be mentioned is that employee's readiness for change has stronger association with employee's commitment for BSC implementation than their leaders' political commitments. Hence, the leaders need to focus on influencing change readiness because, it is better in explaining commitment for change than leader's own political commitment. We argues that if employees are mentally ready for change and committed for implementation of BSC program of their organizations, the reform program will be successful.

\section{CONCLUSION}

This study was aimed at the analysis of the role of political commitment in influencing change readiness and the implementation of BSC reform initiatives in the Ethiopian public sector organizations. Data were collected from 15 organizations of federal government and regional governments of Ethiopia. We found that political commitment of organizational leaders was modest. In relative terms, commitments appear to better in designing reform policies and strategies followed by in making public speech on importance of reforms; however, respondents mostly doubt the adequacy of commitment in allocation of resources for implementation of reforms. We also found that all the dimensions of political commitment had direct linear relations with change readiness. While budgetary commitment and institutional commitment have positive associations with employee commitment for implementing reform, expressed commitment has no linear relationship with employee commitment for implementation of BSC reform. It is also observed that from the types of political commitment: budgetary commitment is the most important factor for employee commitment for reform implementation followed by institutional commitment and expressed commitment.

Based on this observation, we can conclude that political commitment has both 
Political Commitment of Leaders, Change Readiness and Affective Commitment For Implementation of Bsc Reform in Ethiopia

direct and indirect relationship with employee commitment for implementation of BSC reform. However, our dependent variable; employee commitment for implementation of BSC reform has stronger association with employee change readiness than leader's political commitment. The result of correlation shows that the effect size between change readiness and each of the political commitment dimensions is larger than the effect size between affective commitment and each of the dimensions of political commitment. Therefore, the indirect influence of political commitment over affective commitment to implementation of BSC through the intermediary role of change readiness is higher than its direct influence to improve employee commitment for implementation of reforms. Therefore we recommend that in Ethiopian public sector organization, attentions have to be given primarily to enhancing change readiness of employees, which in turn will improve commitment for change.

From all dimensions of political commitment, the role of budgetary commitment was found the highest in having association with change readiness and affective commitment of employees. Hence improving allocation of resources for reform programs implies influencing readiness and commitment of employees. Compared to budgetary and institutional commitment, expressed commitment has the weakest effect in explaining change readiness and affective commitment. Investigation of condition in which expressed commitment may have bigger influence on change readiness and affective commitment can be a topic for future research.

\section{REFERENCES}

- Armenakis, A. A., \& Bedeian, A. G. (1999). Organizational change: A review of theory and research in the 1990s. Journal of Management, 25 (3), 293-315.

- Armenakis, A., Harris, S. G., \& Mossholder, K. W. (1993). Creating Readiness for Organizational Change. Human Relations, 681-703.

- Ashley, Allison, M., Radhika, B., \& J. G and Till, B. (2011). Conceptual and Methodological Challenges to measuring Political Commitment to Respond to HIV. Journal OfInternational AIDS Society.

- Ashley, Yarlini, M., Cheng, B. C., \& and Michael, R. (2014, Appril 6). Measuring Political Commitment and Opportunities to Advance food and Nutrition security:Piloting a rapid assessment tool. Health Policy and Planning , pp. 1-13.

- Ayee, J. R. (2001). Civil service reform in Ghana. African Journal of Politica Science/Revue Africaine de Science Politique, 1-41.

- Berry, F. S. (2007). Government Reform, Public Service Values and the Roles of Public Sector Leadership in Serving Society. .

- Biden, Mziu, \& M.\& Suhaimi, A. (2014). Employing the Balanced Scorecard (BSC) to Measure Performance in Higher Education in Malaysia. , 4, 1. International Journal of Information and Communication Technology Research, 4(1). 
Prestige International Journal of Management E IT-Sanchayan, Vol. 8 (2), 2019, pp. 15-36, ISSN : $2277-1689$ (Print), 2278 - 8441 (Online)

- Burnes, B. (2004). Managing Change. 2nded. London: FT/Prentice-Hal.

- Dewberry, C. (2004). Statistical Methods for Organizational Research: Theory and practice. New York, NY10016, USA: Routledge.

- Fox AM, G. A. (2011). Conceptual and methodological challenges to measuring political commitment to respond to HIV. Journal of the International AIDS Society, 14 (2), 5-18.

- Getachew, H. \&. (2007). Public sector capacity reform in Ethiopia: a tale of success in two ministries. Public Administration and Development, 27 (5), 367-380.

- Hoque, Z. (2013). Celebrating 20 years of the Balanced Scorecard: relevance lost or relevance gained and sustained.

- Israel, H. a. (1986). Country Commitment to Development Project. World Bank Discussion Paper No. 4. Washington DC.

- Jackson, T. A., Meyer, J. P., \& Xiao-Hua (Frank) Wang. (2013). Leadership, Commitment, and Culture: A Meta-Analysis . Journal of Leadership E Organizational Studies, 20 (1), 84-106.

- John, \& P. Meyer and Catherine, A. S. (2000). HRM Practices and Organizational Commitment: Test of a Mediation Model. Canadian Journal of Administrative Science, 17 (4), 319-331.

- Judge, W., \& Douglas, T. (2009). Organizational change capacity: the systematic development of a scale. Journal of Organizational Change Management, 22 (6), 635-649.

- Kiesler, C. (1971). The psychology of commitment: Experiments linking behavior to belief. New York: New YorkAcademic Pres.

- Kotter, J. P. (1995). Leading change: why transformational efforts fail. Harvard Business Review, 59-67.

- Kureshi, N. (2014). To Balanced Scorecard or Not to Balanced Scorecard, That is The Question. Journal of Strategy and Performance Management, 1 (2), 31-38.

- Levy, B. (1993). An institutional analysis of the design and sequence of trade and investment policy reform. The World Bunk Economic Review , 247-262.

- Lewin, K. (1951). Field Theory in Social Science. New York: NY: Holt.

- Lieberman, E. S. (2009). Boundaries of Contagion: How Ethnic Politics have shaped government responses to AIDS. Princeton: Princeton University press.

- Lwin, K. (1947). Frontiers in Group Dynamics. Human Relations , 5-41.

- Morrissey, O. (1995). Political Commitment Institutional Capacity and Tax Policy in Tanzania. World Development, 23 (4), 637-649.

- Nebiyou, B. (2010). Assessment of Public Sector Capacity Building Program/PSCAP/Implementation with Particular Reference to Civil Service Reform SubProgram. Addis Ababa: Unpublished Masters' Thesis.

- Neiger, D. C. (2009). Value-Focused Process Engineering: A Systems Approach; With Applications to Human Resource Management. Integrated Series in Information Systems. Springer.

- Niven, P. R. (2002). Balanced scorecard step-by-step: maximizing performance and maintaining results. John Wiley \& Sons.

- Osborne, \& David, a. T. (1992). Reinventing government. Addison-Wesley.

- Pelletier DL, F. E. (2011). Nutrition agenda setting, policy formulation and implementation: lessons from the mainstreaming nutrition initiative. Health Policy and Planning, 19-31.

- Pettigrew, A. M., Woodman, R. W., \& Cameron, K. S. (2001). Studying organizational change and Development: Challenges for future research. Academy of Management Journal ,697-713. 
- Romanelli, G. a. (2015). Human Resource Management: Balanced Scorecard Approach. Journal of Human Resource Management, 2, 28-32.

- Ronchetti, J. L. (2006). An integrated Balanced Scorecard strategic planning model for nonprofit organizations. . Journal of practical consulting, 1 (1), 25-35.

- Rosen, \& L. and Lydia, M. (2012). Towards a Results-Oriented Public Service in Kenya: The Modern Human Resource Management Perspective. International Journal of Business and Social Science, 3 (21).

- Ruth, A. (2004). Process Model for Organizational Change: Study of Estonian Companies. Journal of Business Economics and Management, 109-117.

- Sinnappan Santhidran, C. J. (2013). Enabiling Organizational Change-Leadership, Commitment to change and the mediating role of change readyness. Journal of Business Economics and Management, 14 (2), 348-363.

- Solomon, M. (2013). Civil Service Reform in Ethiopia: Issues, Lessons, and Future Directions. International Journal of Public Administration, 36 (4), 235-247.

- Strauss, K., Griffin, M. A., \& Rafferty, A. E. (2009). Proactivity Directed Toward the Team and Organization: the Role of Leadership, Commitment and Role-breadth Self-efficacy. British Journal of Management, 279-291.

- Tadesse, E. \&. (2013). Reforms of the public sector in the light of the new public management: A cases of Sub-Saharan Africa. Journal of Public Administration and Policy Research, 5 (1), 1-7.

- Voet, Kuipers, J., \& Grueneveld, S. (2015). Implementing change in public organizations: The relationship between leadership and affective commitment to change in a public sector context. Public Management Review , 1-24.

- Walker, H., Armenaki, A. A., \& Bernerth, J. B. (2007). Factors influencing organizational change efforts: an integrative investigation of change content, context, process and individual differences. Journal of Organizational Change Management,761-773.

- Whitely, A., \& Whitely, J. (2007). Core Values and Organizational Change: Theory and Practice. London: World Scientific.

- Willy, M. (1995). Political Commitment to Reform: Civil Servie Reform in Swaziland. Manchester, Manchester, Britain.

- Yang, K., \& Sanjay K. Pandey. (2008). How Do Perceived Political Environment and Administrative Reform Affect Employee Commitment? . Journal of Public Administration Research and Theory, 335-360.

- Yosef, T. (2011). A Study of the Civil Service Reform in Adama City Administration: Regional State of Oromia-Ethiopia. Addis Ababa University: unpublished Masters' thesis, .

- YPI, L. (2016). Political Commitment and the Value of Partisanship. American Political Science Review, 110 (3), 601-613. 
Prestige International Journal of Management E IT-Sanchayan, Vol. 8 (2), 2019, pp. 15-36, ISSN : 2277-1689 (Print), 2278 - 8441 (Online)

\section{Survey Items}

1 = Strongly Disagree; 2 = Disagree $; 2$ = No opinion; 4 = Agree; 5 = strongly agree

\begin{tabular}{|c|c|c|c|c|c|c|}
\hline & Item related to Expressed commitment & 1 & 2 & 3 & 4 & 5 \\
\hline 1 & $\begin{array}{l}\text { Head of your organization often speak publicly about the urgent need for reform } \\
\text { implementation }\end{array}$ & & & & & \\
\hline 2 & $\begin{array}{l}\text { Other high officials of your organization, often speak publicly about reform } \\
\text { implementation }\end{array}$ & & & & & \\
\hline 3 & $\begin{array}{l}\text { Campaigns have been waged in the past years to raise awareness about importance } \\
\text { of reform implementation }\end{array}$ & & & & & \\
\hline 4 & $\begin{array}{l}\text { Attention of high-level officials to reform implementation has increased in the past } \\
\text { two years }\end{array}$ & & & & & \\
\hline 5 & Your team, leaders often speak about the importance of reform implementation & & & & & \\
\hline \multirow[t]{2}{*}{6} & $\begin{array}{l}\text { When it was adopted I perceived that implementation of BPR/reform is } \\
\text { irrevocable. }\end{array}$ & & & & & \\
\hline & Item related to Institutional Commitment & 1 & 2 & 3 & 4 & 5 \\
\hline 1 & $\begin{array}{l}\text { An intersectoral mechanism that co-ordinates multisectoral reform implementation } \\
\text { programming exists }\end{array}$ & & & & & \\
\hline 2 & The country has adopted a national change and reform policy & & & & & \\
\hline 3 & Your organization has adopted a plan of action for implementing reform programs & & & & & \\
\hline 4 & There is a multisectoral reform program currently operational in the country & & & & & \\
\hline 5 & $\begin{array}{l}\text { There is a national reform implementation strategy that is part of a national } \\
\text { development plan }\end{array}$ & & & & & \\
\hline 6 & There are published national reform guidelines & & & & & \\
\hline \multirow[t]{2}{*}{7} & $\begin{array}{l}\text { Following reform, new regulations has been adopted to change work procedure in } \\
\text { your organization }\end{array}$ & & & & & \\
\hline & Budgetary commitment & & & & & \\
\hline 1 & Facilities required to implement reform is adequately available & & & & & \\
\hline 2 & $\begin{array}{l}\text { All organizational positions are fully staffed with required personnel to implement } \\
\text { reform }\end{array}$ & & & & & \\
\hline 3 & Government allocate enough budget for implementation of reform program & & & & & \\
\hline 4 & $\begin{array}{l}\text { Direct line of communication is established to facilitate direct communication with } \\
\text { higher government officials }\end{array}$ & & & & & \\
\hline 5 & Higher officials are readily available to give direction when you need information & & & & & \\
\hline 6 & $\begin{array}{l}\text { My organization adopted better information and communication technologies } \\
\text { following adoption of reform program }\end{array}$ & & & & & \\
\hline \multirow[t]{2}{*}{7} & Overall rating of resources available for reform implementation program & & & & & \\
\hline & Commitment to reform & 1 & 2 & 3 & 4 & 5 \\
\hline $\mathrm{C} 1$ & I believed in the value of the reform/s. & & & & & \\
\hline $\mathrm{C} 2$ & This reform was a good strategy for this organization. & & & & & \\
\hline C3 & I think that management made a mistake by introducing the reform/s. & & & & & \\
\hline C4 & The reform/s served an important purpose. & & & & & \\
\hline C5 & Things would be better without the reform/s. & & & & & \\
\hline C6 & The reform/s was/were not necessary. & & & & & \\
\hline \multirow[t]{2}{*}{ C7 } & I supported the reform/s. & & & & & \\
\hline & Item related to Change Readiness & & & & & \\
\hline R1 & I was able to perform successfully after the reform/s was/were made. & & & & & \\
\hline R2 & I had the skills that were needed to make the reform/s work. & & & & & \\
\hline R3 & When we implemented the reform/s, I felt I could handle them with ease. & & & & & \\
\hline R4 & When I heard about the reform/s, I thought it suited my skills perfectly. & & & & & \\
\hline R5 & $\begin{array}{l}\text { After the reform/s was/were implemented, I was confident I would be able to do } \\
\text { my job. }\end{array}$ & & & & & \\
\hline R6 & I expected to succeed after the reform/s was/were implemented. & & & & & \\
\hline
\end{tabular}


Political Commitment of Leaders, Change Readiness and Affective Commitment For Implementation of Bsc Reform in Ethiopia

\section{Frequency Table}

\begin{tabular}{|c|c|c|c|c|c|}
\hline \multicolumn{6}{|c|}{ Organization of respondents } \\
\hline & & Frequency & Percent & Valid Percent & $\begin{array}{l}\text { Cumulative } \\
\text { Percent }\end{array}$ \\
\hline \multirow{15}{*}{ Valid } & 1. Oromia Education Bureau & 18 & 7.3 & 9.4 & 9.4 \\
\hline & 2. Oromia Trade Bureau & 8 & 3.3 & 4.2 & 13.6 \\
\hline & 3. Addis Ababa TVET Bureau & 25 & 10.2 & 13.1 & 26.7 \\
\hline & $\begin{array}{l}\text { 4. Addis Ababa Capacity } \\
\text { Building Bureau }\end{array}$ & 7 & 2.9 & 3.7 & 30.4 \\
\hline & $\begin{array}{l}\text { 5. Addis Ababa women and } \\
\text { children Bureau }\end{array}$ & 5 & 2.0 & 2.6 & 33.0 \\
\hline & 6. FDRE Ministry of education & 2 & .8 & 1.0 & 34.0 \\
\hline & $\begin{array}{l}\text { 7. Agency for Research and } \\
\text { Conservation of cultural } \\
\text { Heritage }\end{array}$ & 16 & 6.5 & 8.4 & 42.4 \\
\hline & $\begin{array}{l}\text { 8. Ministry of Urban and } \\
\text { Housing }\end{array}$ & 22 & 9.0 & 11.5 & 53.9 \\
\hline & 9. SNNPR Revenue Authority & 22 & 9.0 & 11.5 & 65.4 \\
\hline & $\begin{array}{l}\text { 10. Addis Ababa Public Service } \\
\text { and HRD }\end{array}$ & 20 & 8.2 & 10.5 & 75.9 \\
\hline & $\begin{array}{l}\text { 11. Oromia Natural resource } \\
\text { and Environment Bureau }\end{array}$ & 15 & 6.1 & 7.9 & 83.8 \\
\hline & 12. Oromia Revenues Authority & 11 & 4.5 & 5.8 & 89.5 \\
\hline & $\begin{array}{l}\text { 13. Somali Region Culture and } \\
\text { Tourism Bureau }\end{array}$ & 12 & 4.9 & 6.3 & 95.8 \\
\hline & $\begin{array}{l}\text { 14. Somali Region Revenues } \\
\text { Authority }\end{array}$ & 8 & 3.3 & 4.2 & 100.0 \\
\hline & Total & 191 & 78.0 & 100.0 & \\
\hline Missing & System & 54 & 22.0 & & \\
\hline Total & & 245 & 100.0 & & \\
\hline
\end{tabular}

\begin{tabular}{|c|c|c|c|c|c|c|}
\hline \multirow[t]{2}{*}{ Respondents } & \multicolumn{2}{|c|}{ Age group } & \multirow{2}{*}{$\begin{array}{r}\text { Frequency } \\
38 \\
\end{array}$} & \multirow{2}{*}{\begin{tabular}{r|} 
Percent \\
15.5 \\
\end{tabular}} & \multirow{2}{*}{$\begin{array}{r}\text { Valid Percent } \\
20.2 \\
\end{array}$} & \multirow{2}{*}{$\begin{array}{l}\begin{array}{l}\text { Cumulative } \\
\text { Percent }\end{array} \\
20.2 \\
\end{array}$} \\
\hline & \multirow{5}{*}{ Valid } & $18-30$ & & & & \\
\hline \multirow[t]{8}{*}{ Age } & & $31-43$ & 92 & 37.6 & 48.9 & 69.1 \\
\hline & & \begin{tabular}{|l|}
$44-56$ \\
\end{tabular} & 52 & 21.2 & 27.7 & 96.8 \\
\hline & & $57 \&$ above & 6 & 2.4 & 3.2 & 100.0 \\
\hline & & Total & 188 & 76.7 & 100.0 & \\
\hline & \multirow{3}{*}{ Missing } & 9 & 3 & 1.2 & & \\
\hline & & System & 54 & 22.0 & & \\
\hline & & Total & 57 & 23.3 & & \\
\hline & \multicolumn{2}{|l|}{ Total } & 245 & 100.0 & & \\
\hline \multirow{9}{*}{$\begin{array}{c}\text { Sex of } \\
\text { respondents }\end{array}$} & & & & & & \\
\hline & & & Frequency & Percent & Valid Percent & $\begin{array}{c}\text { Cumulative } \\
\text { Percent }\end{array}$ \\
\hline & \multirow{3}{*}{ Valid } & Male & 128 & 52.2 & 74.4 & 74.4 \\
\hline & & Female & 44 & 18.0 & 25.6 & 100.0 \\
\hline & & Total & 172 & 70.2 & 100.0 & \\
\hline & \multirow{3}{*}{ Missing } & 9 & 19 & 7.8 & & \\
\hline & & System & 54 & 22.0 & & \\
\hline & & Total & 73 & 29.8 & & \\
\hline & \multicolumn{2}{|l|}{ Total } & 245 & 100.0 & & \\
\hline
\end{tabular}


Prestige International Journal of Management E IT-Sanchayan, Vol. 8 (2), 2019, pp. 15-36, ISSN : $2277-1689$ (Print), 2278 - 8441 (Online)

\begin{tabular}{|c|c|c|c|c|c|c|}
\hline \multirow{9}{*}{$\begin{array}{l}\text { Educational } \\
\text { level } \\
\text { attained }\end{array}$} & & & Frequency & Percent & Valid Percent & $\begin{array}{c}\text { Cumulative } \\
\text { Percent }\end{array}$ \\
\hline & \multirow{4}{*}{ Valid } & $\begin{array}{l}\text { Diploma and } \\
\text { Below }\end{array}$ & 7 & 2.9 & 3.8 & 3.8 \\
\hline & & Firs Degree & 135 & 55.1 & 73.0 & 76.8 \\
\hline & & $\begin{array}{l}\text { Second Degree } \\
\text { and Above }\end{array}$ & 43 & 17.6 & 23.2 & 100.0 \\
\hline & & Total & 185 & 75.5 & 100.0 & \\
\hline & \multirow{3}{*}{ Missing } & 9 & 6 & 2.4 & & \\
\hline & & System & 54 & 22.0 & & \\
\hline & & Total & 60 & 24.5 & & \\
\hline & \multicolumn{2}{|l|}{ Total } & 245 & 100.0 & & \\
\hline \multirow{11}{*}{$\begin{array}{l}\text { Year of } \\
\text { experience } \\
\text { of } \\
\text { respondent }\end{array}$} & & & Frequency & Percent & Valid Percent & $\begin{array}{c}\text { Cumulative } \\
\text { Percent }\end{array}$ \\
\hline & \multirow{6}{*}{ Valid } & $\begin{array}{l}\text { Less than } 5 \\
\text { years }\end{array}$ & 67 & 27.3 & 35.3 & 35.3 \\
\hline & & $6-10$ years & 51 & 20.8 & 26.8 & 62.1 \\
\hline & & 11-15 Years & 22 & 9.0 & 11.6 & 73.7 \\
\hline & & 16-20 Years & 25 & 10.2 & 13.2 & 86.8 \\
\hline & & $21 \&$ Above & 25 & 10.2 & 13.2 & 100.0 \\
\hline & & Total & 190 & 77.6 & 100.0 & \\
\hline & \multirow{3}{*}{ Missing } & 9 & 1 & .4 & & \\
\hline & & System & 54 & 22.0 & & \\
\hline & & Total & 55 & 22.4 & & \\
\hline & \multicolumn{2}{|l|}{ Total } & 245 & 100.0 & & \\
\hline
\end{tabular}

